Variation of Antioxidant Activity and Total Phenolic Content of Tea (Camellia sinensis L. O. Kuntze) Genotypes

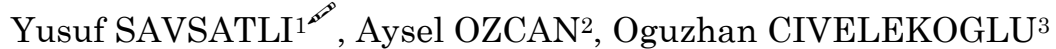 \\ ${ }^{1,2}$ Recep Tayyip Erdogan University, Faculty of Agriculture, Field Crops Department, Rize/Turkey, ${ }^{3}$ General Secretaryship of The National \\ Tea Council, Rize Commodity Exchange, Rize/Turkey. \\ 1https://orcid.org/0000-0001-9246-6710, ${ }^{2}$ https://orcid.org/0000-0001-5210-7617, ${ }^{3 h t t p s: / / o r c i d . o r g / 0000-0003-1542-4896 ~}$ \\ 凶: yusuf.savsatli@erdogan.edu.tr
}

\section{ABSTRACT}

This study was carried out to determine tea (Camellia sinensis L. O. Kuntze) genotypes with high antioxidant activity and also high total phenolic content (TPC) in Rize/Turkey conditions in 2017. In the research, the seeds collected from tea plantations located at different five locations of Rize were used. Plants were grown under controlled conditions in pots in greenhouse at first and then transferred to field conditions. Harvest of fresh leaves was realized for 3.5 leaves (three leaves and bud) in August. Ferric-Reducing Antioxidant Power (FRAP) and total phenol content of young leaves of selected 103 genotypes were determined. As a result, FRAP values varied between 638.4 and $1093.0 \mathrm{mg} \mathrm{FeSO}_{4} \mathrm{~g}-1 \mathrm{dw}$ while total phenol content varied from 210.9 to $450.6 \mathrm{mg}$ GAE g-1 dw depending on the genotypes. FRAP values belonging each genotype group representing locations were very close to each other. On the other hand, 87 of a total of 103 genotypes had high antioxidant values. The fact that the genotypes showed a high level of antioxidant activity and total phenol content reveals the presence of evaluable tea genotypes to be used in tea breeding in Rize.

Research Article
$\begin{array}{ll}\text { Article History } \\ \text { Received } \quad: 29.05 .2020 \\ \text { Accepted } \quad: 09.07 .2020\end{array}$

Keywords
Tea
Genotype
FRAP
TPC

\title{
Çay (Camellia sinensis L. O. Kuntze) Genotiplerinde Antioksidan Aktivite ve Toplam Fenolik İçeriğindeki Varyasyon
}

\section{ÖZET}

$\mathrm{Bu}$ çalışma toplam fenolik içeriği (TPC) ve antioksidan aktivitesi yüksek çay (Camellia sinensis (L.) O. Kuntze) genotiplerinin belirlenmesi amacıyla Rize/Türkiye koşullarında 2017 yılında yürütülmüştür. Araştırmada, Rize'nin farklı lokasyonlarında yer alan çay plantasyonlarından toplanmış tohumlar kullanılmıştır. Saksılarda kontrollü koşullarda yetiştirilen bitkiler daha sonra açık hava koşullarına taşınmıştır. Genç yaprakların hasadı, Ağustos ayı içinde 3.5 yaprak üzerinden yapılmıştır. Liyofilizatörde kurutulan toplam 103 genotipe ait taze yaprakların antioksidan değerleri ve toplam fenol içerikleri tespit edilmiştir. Sonuç olarak, incelenen genotipler içinde elde edilen ortalama FRAP değerleri 638.4-1093.0 mg $\mathrm{FeSO}_{4} \mathrm{~g}^{-1}$ kuru ağırlık; toplam fenol içeriği ise 210.9-450.6 mg GAE g-1 kuru ağırlık arasında değişim göstermiştir. Lokasyonları temsil eden her bir genotip grubuna ait ortalama FRAP değerleri birbirine çok yakın çıkmıştır. Diğer taraftan, toplam 103 genotip içinden 87 tanesi yüksek antioksidan değerlere sahip olmuştur. Genotiplerin yüksek düzeyde antioksidan aktivite ve toplam fenol içeriği göstermesi, Rize'de çay yetiştiriciliğinde kullanılabilecek değerli çay genotiplerinin varlığını ortaya koymaktadır.

\section{Araştırma Makalesi}

$\begin{array}{ll}\text { Makale Tarihçesi } \\ \text { Geliş Tarihi } & : 29.05 .2020 \\ \text { Kabul Tarihi } & : 09.07 .2020\end{array}$

Anahtar Kelimeler
Çay
Genotip
FRAP
TPC

To Cite : Savsatli Y, Ozcan A, Civelekoglu O 2021. Variation of Antioxidant Activity and Total Phenolic Content of Tea (Camellia sinensis L. O. Kuntze) Genotypes. KSU J. Agric Nat 24 (1): 40-48. https://doi.org/10.18016/ksutarimdoga. vi.744662.

\section{INTRODUCTION}

Tea is a valuable plant of the family Theaceae
(Weisburger, 1997) and three different types of tea grown widely in the world. Camellia sinensis var. 
L.O. Kuntze is a species of tea grown in Turkey (Taylor, 2003). The young leaves of this species, particularly suitable for green tea production and contain useful antioxidant components (Tariq and Reyaz, 2013; Nibir et al., 2017). Natural antioxidants are important components that strengthen the defense system in body and have beneficial effects on health (Öğüt, 2014). Therefore, nutritional values and benefits of fruits are closely followed by consumers (Scalzo et al., 2005). This tendency of consumers has led to the fact that breeding studies are concentrating on increasing efficiency of the products which are consumed intensively on health nowadays. The amounts of bioactive components, total phenolic content and antioxidant effects of the harvested products vary according to plant species. Sirisa-Ard et al. (2017) reported that total phenolic content of fermented Miang varried between $147.48 \pm 0.006$ and $438.51 \pm 0.018 \mathrm{mg}^{\mathrm{GAE}} \mathrm{g}^{-1} \mathrm{dw}$ while the antioxidant activity values (TEAC) of that varried between $5,578.34 \pm 0.019 \mathrm{mg} \mathrm{g}^{-1} \mathrm{dw}$ and $18,315.21 \pm 0.022 \mathrm{mg} \mathrm{g}^{-1}$ $\mathrm{dw}$. Especially green tea is known as a source of beneficial antioxidants (Graham, 1992). Since green tea is obtained by processing fresh leaves without fermenting, the closest results to the content of this tea type can undoubtedly be obtained by analysis of fresh tea leaves. It is reported that antioxidant activity in green tea is similar to that of white tea because of the high levels of EGCG (Epigallocatechin Gallate) and ECG (Epicatechin Gallate), which are the strongest antioxidants in young tea leaves (Karori et al., 2007). There are many studies showing that the high amounts of antioxidant components in tea leaves are anticancergenic (Wang and Bachrach, 2002; Hayakawa et al., 2016; Vishnoi et al., 2018; Mir et al., 2019). In the production of tea products with high antioxidant capacity, cultivation of genotypes with high potential of polyphenols in appropriate ecologies and under suitable conditions can be significantly effective.

Liu et al. (2008) reported that the highest FRAP value among the 68 plant materials in China was Chinese White Olive with $15.853 \mathrm{mmol} \mathrm{FeII} \mathrm{g-1} \mathrm{dw.} \mathrm{In}$ another study, antioxidant values in parts of 33 medicinal and edible plants grown in China varied between $2.1 \mu \mathrm{mol} \mathrm{FeSO}_{4} \mathrm{~g}^{-1} \mathrm{dw}$ and $4790.1 \mu \mathrm{mol}$ $\mathrm{FeSO}_{4} \mathrm{~g}^{-1} \mathrm{dw}$ (Jiang et al., 2011). The highest FRAP value was obtained from floral buds of Flos Caryophylli and followed by leaves of Camellia sinensis $\mathrm{L}$. with $2433.9 \mathrm{\mu mol} \mathrm{FeSO}_{4} \mathrm{~g}^{-1} \mathrm{dw}$.

In recent years, focused on studies to increase the specific bioactive components of various plants. As a matter of fact, Capocasa et al. (2008) have shown that nutrient characteristics and quality of strawberries can be increased by crossing. Likewise, antioxidant properties of varieties are taken into consideration in potato (Stushnoff et al., 2008), Peach and Nectarine
(Cantin et al., 2009) in breeding programs while bioactive components in many medical and aromatic plants are overemphasized.

Rich in flavonol glycosides, which are related to antioxidant potential, are reported to be used effectively in breeding programs (Jeganathan et al., 2016). Green tea and black tea are rich in antioxidants (Shannon et al., 2018) and are widely consumed in almost all populations (Van et al., 1997). Therefore, it can be seen as a great chance to make the most of tea consumed extensively in the world.

Tea plant is highly allogamous nature due to selfsterility. This makes progeny from seed possible to produce a wide variation in productivity and other characters and to be used this variation (Waheed et al., 2001). As a matter of fact, there are many improved cultivars either by crossing (Benihikari, Okuhikari, Okumidori, Tsuyuhikari, Saemidori ect.) or via selection (Yabukita, Yutakamidori, Utakamidori, Benihomare ect.) from tea plantations in the world (Yagi et al., 2010).

This study was conducted to determine antioxidant activity and total phenolic content of young leaves of the genotypes multiplicated from seeds collected from different locations in Rize/Turkey and to reveal present variation which is important for breeders.

\section{MATERIAL and METHODS}

In this study, seeds (5 seeds per each plant and total of 515 seeds) were collected in total of 103 different plants from tea fields located on five different places in Rize province where has the most tea plantation in Turkey. Locations (L) from where the tea seeds were collected are given in Table 1.

Table 1. Genotype groups belonging to tea seeds collected according to different locations (L)

Cizelge 1. Farkll lokasyonlara göre toplanan çay tohumlarına ait genotip gruplar

\begin{tabular}{lll}
\hline Genotype group & Location & Number of material \\
\hline L1 & Location-1 & 41 \\
L2 & Location-2 & 20 \\
L3 & Location-3 & 17 \\
L4 & Location-4 & 15 \\
L5 & Location-5 & 10 \\
\hline & Total & 103 \\
\hline
\end{tabular}

L1 and L3 are adjacent to each other as well as L2 and L4. On the other hand, average distance from L5 to L1-L3 is $7.1 \mathrm{~km}$, and distance to L2-L4 is $32.3 \mathrm{~km}$ (Figure 1).

The seeds taken from each plant were sown in the same pot in March 2017 and grown in greenhouse conditions. One of the best growing seedlings was left in every pot and others removed from pods. Thus, 
$80 \%$ of total 515 tea plants were initially eliminated in the seedling stage.

The plants were kept in the greenhouse until they were strengthened and then taken out of the greenhouse. Plants growing in pots when reached sufficient growth were harvested once by hand in
August. Overall, 3.5 leaves (three leaf and bud) were harvested from each plant. The harvested fresh leaves were kept in lyophilizer until dry, and antioxidant activities and total phenolic content of leaf samples were determined after methanol extraction.

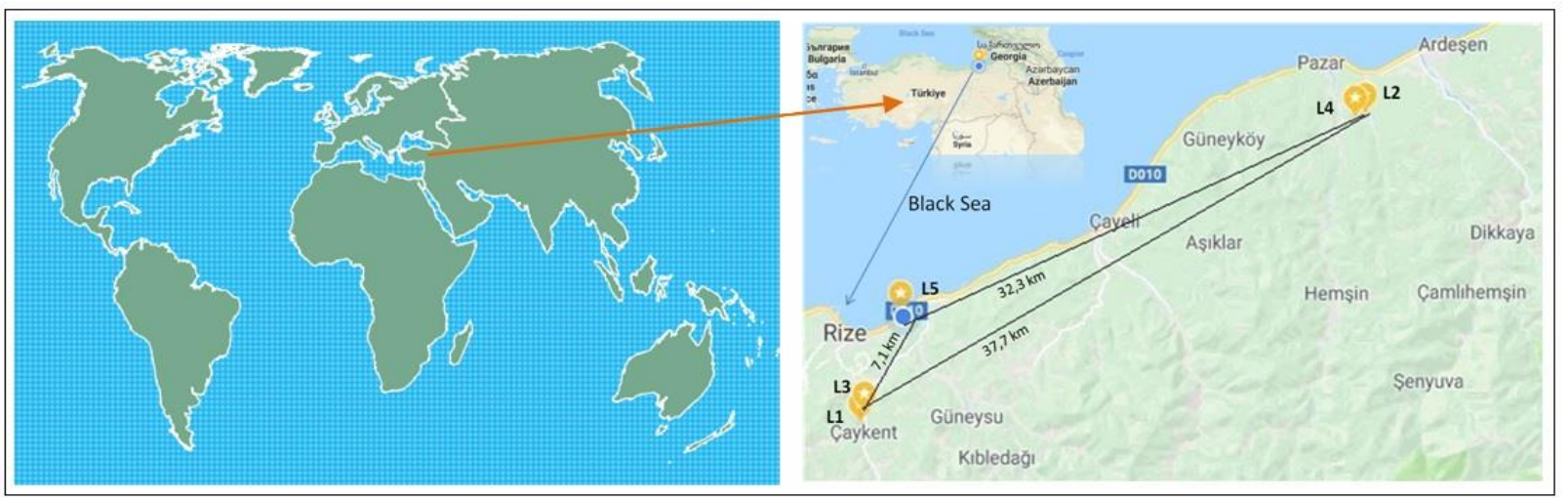

Figure 1. Locations containing genotype groups

Şekil 1. Genotip grupları içeren lokasyonlar

\section{Extraction of Samples}

The fresh tea leaves were dried in a lyophilizer with Labconco brand and powdered in a porcelain mortar. Then, $0.1 \mathrm{~g}$ of each powdered sample was extracted in $10 \mathrm{ml}$ methanol $(80 \%)$ at $40{ }^{\circ} \mathrm{C}$ using an orbital shaking for 1 hour. The sample-solvent mixture was centrifuged at $4000 \mathrm{rpm}_{\text {minute }}^{-1}$ for 20 minutes. The supernatants were separated from the mixture and analyzed for the determination of antioxidant activity and total phenol content.

\section{Ferric-Reducing Antioxidant Power (FRAP)}

The method of Benzie and Strain (1996) was used by modifying in the analysis of the samples. Buffer solution prepared by mixing $200 \mathrm{ml}$ of acetate buffer $(\mathrm{pH} 3.6), 20 \mathrm{ml}$ of 2,4,6-tripyridyl-s-triazine (TPTZ) solution and $20 \mathrm{ml}$ of ferric chloride $\left(\mathrm{FeCl}_{3} .6 \mathrm{H}_{2} \mathrm{O}\right)$ solution in a ratio of 10:1:1 as FRAP (Iron reduction antioxidant capacity) reagent. $\mathrm{HCl}$ was used to dissolve these chemicals while the buffer solution was preparing. Overaall, $20 \mu \mathrm{l}$ sample (supernant) was added to a total of $1980 \mu \mathrm{l}$ FRAP reagent and value was read using UV Spectrophotometer (Shimadzu UV-1800 brand) at $593 \mathrm{~nm}$ wavelength. A standard curve was obtained from known $\mathrm{Fe}$ (II) $\left(\mathrm{FeSO}_{4}\right)$ concentrations $(5 \mu \mathrm{l}, 10 \mu \mathrm{l}, 15 \mu \mathrm{l}$ and $20 \mu \mathrm{l})$. FRAP values of the samples were determined according to standard curve. The results were expressed as $\mathrm{mg}$ of iron (II) sulfate $\left(\mathrm{FeSO}_{4}\right)$ equivalents per gram dried weight $(\mathrm{dw})$ of the sample.

\section{Total of Phenolic Content (TPC)}

Total phenolic content of samples was determined using the Folin-Ciocalteau method (Waterhouse, 2002). $20 \mu \mathrm{l}$ of the supernant and $100 \mu \mathrm{l}$ of Folin-
Ciocalteau reagent were added to $1580 \mu \mathrm{l}$ of distilled water. Subsequently, $300 \mu \mathrm{l}$ of $\mathrm{Na}_{2} \mathrm{CO}_{3}$ (Sodium carbonate solution) was added into the mixture. The final solution was incubated at $50{ }^{\circ} \mathrm{C}$ for 15 minute and values of absorbance were measured at $765 \mathrm{~nm}$ using the Spectrophotometer. Values of gallic acid of the samples were determined according to standard curve. The results were expressed as mg of gallic acid equivalents (GAE) per gram dried weight (dw) of the samples.

\section{Statistical Analysis}

Values for each genotype group (L1, L2, L3, L4 and L5) were analyzed separately as completely randomized design with 3 replications using JMP statistical program. The means were separated by the Tukey HSD (Honestly Significant Difference) test.

\section{RESULTS and DISCUSSION}

In the study, fresh leaves of genotypes obtained from seeds collected from different locations were compared in terms of antioxidant activity and total phenolic content (Table 2 and Table 3). The antioxidant values were between 638.4 and $1093.0 \mathrm{mg}$ $\mathrm{FeSO}_{4} \mathrm{~g}^{-1} \mathrm{dw}$ while the total phenolic content varied from 210.9 to $450.6 \mathrm{mg} \mathrm{GAE} \mathrm{g}^{-1} \mathrm{dw}$ depending on the genotypes (Figure 2, 3, 4).

On the other hand, when considering the average of each genotype group, this variation ranged from 900.4 to $950.3 \mathrm{mg} \mathrm{FeSO}_{4} \mathrm{~g}^{-1} \mathrm{dw}$ in terms of average antioxidant activity and from 285.1 to $321.2 \mathrm{mg}$ GAE $\mathrm{g}^{-1} \mathrm{dw}$ for total phenolic content.

In the research, there was a significant $(\mathrm{P}<0.01)$ positive correlation $(\mathrm{r}=0.342)$ between antioxidant activity and total phenolic content (Figure 5). Similar 
to these results, many investigators reported that there was a significant correlation between these traits (Anesini et al., 2008; Liu et al., 2008; Rusak et al., 2008; Jayasekera et al., 2011; Jiang et al., 2011). Therefore, the content of phenolic compounds could be used as an important indicator of its antioxidant capacity. The antioxidant values in 27 of 103 genotypes grown in Rize exceeded $1000 \mathrm{mg} \mathrm{FeSO}_{4} \mathrm{~g}^{-1}$ dw. The lowest FRAP value among the genotypes which was statistically in the group "a" belonged to genotype number 88 with $857.2 \mathrm{mg} \mathrm{FeSO}_{4} \mathrm{~g}^{-1} \mathrm{dw}$. Total number of genotypes with FRAP values above this value was 87 . This result shows that $84.5 \%$ of the genotypes used are primarily antioxidant-rich and only $15.5 \%$ of the existing genotypes should be eliminated.

Tea Research Foundation, in Africa, reported that number of the material was reduced from 5000 genotypes to 350 genotypes by plant selection on rooting ability and nursery performance in the first years of the breeding program for new cultivars (Apostolides et al., 2006). In this breeding program, it is seen that a large number of genotypes were eliminated at the beginning and $7 \%$ of total number of genotypes was selected as important material. But in present study, a total of 515 genotypes collected from different locations were reduced to 103 genotypes in terms of seedling vigour at first. A large parts of this genotypes (87 genotypes), which was $16.9 \%$ of the initial number, showed high antioxidant activity.

The genotypes within each group were considered separately and the numerical ratios of those in terms of rich in antioxidant activity were calculated. $93.3 \%$ of the genotypes in the L4 genotype group had high antioxidant activity. This rate was followed by L5 with $90.0 \%$, L1 with $85.4 \%$, L2 with $80.0 \%$ and L3 genotype group with $76.5 \%$ respectively. These differences among the genotype groups are entirely due to genetic factors.

In a research on antioxidant activites of different green teas, FRAP values were found to vary between 0.554-2.876 mmol FeII g-1 (Hajimahmoodi et al., 2008). Rusak et al. (2008) determined FRAP values generally between $4.02-17.9 \mathrm{mmol} \mathrm{L}^{-1} \mathrm{Fe} 2+$ in white tea and $2.45^{-19.0} \mathrm{mmol} \mathrm{L}^{-1} \mathrm{Fe} 2+$ in green tea depending on the methods. Ercisli et al. (2008) reported that total phenolic content of fresh tea leaves of Derepazari-7 tea clone growing in Rize conditions varied with harvest periods (July $>$ May=September) and that the highest value was obtained in the July 15 harvest. Erturk et al. (2010) showed that the values obtained from 2.5 leaves (consisting of fresh tea shoots) were changed according to tea clones and the highest value was found at the 3rd harvest period (September) in Pazar 20 clone with a mean of 291.8 mg GAE g-1 dw. In another study conducted in Rize, Yazici and Goksu (2017) found that FRAP values of fresh tea leaves varied between $5.00 \pm 0.90$ and $5.93 \pm 0.45 \mathrm{mmol}^{\mathrm{FeSO}} 4 \mathrm{~g}^{-1} \mathrm{dw}$, and total phenolic content varied between $112.88 \pm 4.19$ and $131.64 \pm 4.52$ mg GAE $\mathrm{g}^{-1} \mathrm{dw}$.

In a study conducted by Nor Qhairul Izzreen and Mohd Fadzelly (2013) in Malaysia, antioxidant activity and total phenolic content in green tea and black tea produced by processing tea leaves according to the maturity level (shoots, young and mature leaves) were compared. In the study, the highest FRAP value was achieved in green tea (from shoots) with $14.83 \pm 0.21 \mu \mathrm{mol} \mathrm{Fe}_{2} \mathrm{SO}_{4} .7 \mathrm{H}_{2} \mathrm{O} \mathrm{ml} \mathrm{m}^{-1}$. In the same study, the values obtained for TPC ranged from 56.63 (green tea from shoots) to $80.27 \mathrm{mg} \mathrm{GAE} \mathrm{g}^{-1} \mathrm{dw}$ (black tea from mature). Oh et al. (2013) reported that total phenolic content in green tea was $144.52 \pm 5.36 \mathrm{mg}$ GAE g-1 dw.

There are differences in the units of FRAP values calculated in some studies carried out before. When a comparison is made by unit conversions, the values obtained in the present study are between the values determined by Rusak et al. (2008) and above reported by Hajimahmoodi et al., (2008) and Yazici and Goksu (2017). Similarly, the data obtained in the present study with respect to the total phenolic content are above the values stated by Ercisli et al. (2008), Erturk et al. (2010), Nor Qhairul Izzreen and Mohd Fadzelly (2013), Oh et al. (2013) and Yazici and Goksu (2017). In another study conducted in Malaysia, total phenolic content of Iran-100 tea clone was limited to $8.44 \pm 1.03 \mathrm{mg}$ gallic acid equivalents (Gonbad et al., 2015). This value is too below the values obtained in present study.

Differences in the values obtained from different studies for antioxidant activity and total phenolic content may be due to the phenolic composition and quality of tea, and several other factors including preharvest and post-harvest conditions (Tounekti et al., 2013). These important factors also include genetic differences (Erturk et al., 2010), different environmental conditions (Hajiboland et al., 2011; Kaur et al., 2014), harvest season (Jayasekea et al., 2011), pruning age (Savsatli et al., 2018), harvest standards and frequency (Kaur et al., 2014), analysis methods (Rusak et al., 2008), manufacturing process (Carloni et al., 2013, Benzie and Szeto, 1999), type of tea (Karori et al., 2007; Tounekti et al., 2013).

\section{CONCLUSION}

Tea genotypes multiplicated from seeds collected from different locations of Rize produced leaves were rich in antioxidant activity and total phenolic content. The fact that the genotypes investigated in the study showed naturally high levels of antioxidant activity and total phenolic content. These results clearly prove that it is possible that these genotypes reached to high quality for tea breeding. 
Table 2. Ferric-reducing antioxidant power (FRAP) ( $\mathrm{mg} \mathrm{FeSO}_{4} \mathrm{~g}^{-1} \mathrm{dW}$ ) in genotypes belonging to different locations $(L)$

Cizelge 2. Farkl lokasyonlara (L) ait genotiplerin demir indirgenme antioksidan kapasitesi (FRAP) $\left(\mathrm{mg} \mathrm{FeSO}_{4} \mathrm{~g}^{-1} \mathrm{dW}\right)$

\begin{tabular}{|c|c|c|c|c|c|c|c|c|c|c|c|}
\hline \multicolumn{4}{|c|}{ L1 } & \multicolumn{2}{|r|}{ L2 } & \multicolumn{2}{|r|}{ L3 } & \multicolumn{2}{|r|}{ L4 } & \multicolumn{2}{|r|}{ L5 } \\
\hline No & FRAP $\mathbf{S x}$ & No & FRAP Sx & No & FRAP & No & FRAP Sx & No & FRAP Sx & No & FRAP Sx \\
\hline 1. & $1042.7 \pm 3.5^{\mathrm{a}-\mathrm{d}}$ & 22. & $906.9 \pm 106.9 a^{a-f}$ & 42. & $1015.7 \pm 11.7 \mathrm{a}^{-\mathrm{c}}$ & 62. & $812.7 \pm 30.1^{\mathrm{c}^{-} \mathrm{e}}$ & 79. & $999.9 \pm 80.8^{a}$ & 94. & $908.8 \pm 46.2^{\mathrm{a}-c}$ \\
\hline 2. & $910.6 \pm 11.3 \mathrm{a}-\mathrm{f}$ & 23. & $881.7 \pm 57.2$ a-f & 43. & $871.8 \pm 17.3$ b-e & 63. & $932.5 \pm 22.9 \mathrm{a}^{\mathrm{a} c \mathrm{c}}$ & 80. & $894.0 \pm 35.6$ ab & 95. & $974.8 \pm 4.0 \mathrm{ab}$ \\
\hline 3. & $1030.3 \pm 2.7 \mathrm{a}^{-\mathrm{d}}$ & 24. & $1063.3 \pm 24.5^{\mathrm{a}-\mathrm{c}}$ & 44. & $1067.3 \pm 4.8^{\mathrm{a}-\mathrm{b}}$ & 64. & $869.1 \pm 15.2^{\mathrm{b}-\mathrm{d}}$ & 81. & $866.5 \pm 10.6$ ab & 96. & $974.9 \pm 29.4 \mathrm{ab}$ \\
\hline 4. & $815.6 \pm 8.0 \mathrm{~d} \cdot \mathrm{f}$ & 25. & $933.9 \pm 42.2^{\mathrm{a}-\mathrm{f}}$ & 45. & $1047.3 \pm 8.8 \mathrm{ab}$ & 65. & $745.8 \pm 26.2 \mathrm{~d}-\mathrm{f}$ & 82. & $964.0 \pm 13.0 \mathrm{ab}$ & 97. & $954.2 \pm 12.0$ ac \\
\hline 5. & $912.7 \pm 8.4 \mathrm{a}^{\mathrm{a} f}$ & 26. & $934.9 \pm 24.1$ a-f & 46. & $1019.4 \pm 20.1^{\mathrm{a}-\mathrm{c}}$ & 66. & $1046.7 \pm 15.0 \mathrm{a}$ & 83. & $912.2 \pm 9.2 \mathrm{ab}$ & 98. & $828.2 \pm 15.0^{c}$ \\
\hline 6. & $859.9 \pm 4.4^{a-f}$ & 27. & $1001.2 \pm 16.2^{\mathrm{a}-\mathrm{d}}$ & 47. & $929.9 \pm 46.8$ a-e & 67. & $908.0 \pm 30.7 \mathrm{a}^{-c}$ & 84. & $937.3 \pm 46.7 \mathrm{ab}$ & 99. & $922.6 \pm 1.8^{\mathrm{a}-\mathrm{c}}$ \\
\hline 7. & $719.3 \pm 8.0^{\mathrm{f}}$ & 28. & $1043.5 \pm 13.3^{\mathrm{a}-\mathrm{d}}$ & 48. & $855.7 \pm 35.2^{\mathrm{c}-\mathrm{e}}$ & 68. & $685.9 \pm 46.2$ ef & 85. & $970.6 \pm 51.8^{a b}$ & 100. & $971.0 \pm 32.6 \mathrm{ab}$ \\
\hline 8. & $1007.8 \pm 13.2^{\mathrm{a}-\mathrm{d}}$ & 29. & $938.5 \pm 6.3 \mathrm{a}-\mathrm{f}$ & 49. & $894.5 \pm 12.0$ a-e & 69. & $990.6 \pm 32.3 \mathrm{ab}$ & 86. & $974.9 \pm 75.2^{\mathrm{a}}$ & 101. & $1038.6 \pm 24.2^{\mathrm{a}}$ \\
\hline 9. & $1028.4 \pm 8.8^{a^{-d}}$ & 30. & $1047.6 \pm 15.4^{\mathrm{a}-\mathrm{d}}$ & 50. & $951.6 \pm 23.8$ a-e & 70. & $978.5 \pm 27.3 \mathrm{ab}$ & 87. & $958.9 \pm 57.3$ ab & 102. & $1022.4 \pm 37.8 \mathrm{ab}$ \\
\hline 10. & $878.6 \pm 6.4^{\mathrm{a}-\mathrm{f}}$ & 31. & $962.3 \pm 19.3 a^{a-e}$ & 51. & $904.8 \pm 12.4$ a-e & 71. & $924.1 \pm 52.1^{\mathrm{a}-\mathrm{c}}$ & 88. & $857.2 \pm 28.6$ ab & 103. & $907.4 \pm 17.3 \mathrm{bc}$ \\
\hline 11. & $1078.1 \pm 5.8 \mathrm{ab}$ & 32. & $873.1 \pm 24.5$ a-f & 52. & $960.7 \pm 54.6^{\mathrm{a}-\mathrm{d}}$ & 72. & $998.8 \pm 18.0 \mathrm{ab}$ & 89. & $986.7 \pm 25.7$ a & & \\
\hline 12. & $950.5 \pm 8.0 \mathrm{a}-\mathrm{f}$ & 33. & $841.8 \pm 9.3 \mathrm{~b}-\mathrm{f}$ & 53. & $752.9 \pm 72.2 \mathrm{e}$ & 73. & $952.9 \pm 9.0{ }^{\mathrm{a}-\mathrm{c}}$ & 90. & $1089.6 \pm 14.3 \mathrm{a}$ & & \\
\hline 13. & $925.5 \pm 10.5$ a-f & 34. & $979.2 \pm 22.6 \mathrm{a}^{\mathrm{a}-\mathrm{d}}$ & 54. & $883.9 \pm 34.4$ a-e & 74. & $935.7 \pm 50.9 a^{a^{-c}}$ & 91. & $956.7 \pm 61.9 \mathrm{ab}$ & & \\
\hline 14. & $723.0 \pm 1.9$ e-f & 35. & $1080.5 \pm 28.6 \mathrm{ab}$ & 55. & $796.5 \pm 59.6 \mathrm{~d}^{\mathrm{d}-\mathrm{e}}$ & 75. & $955.6 \pm 2.1^{\mathrm{a}-\mathrm{c}}$ & 92. & $730.8 \pm 49.0^{b}$ & & \\
\hline 15. & $1004.5 \pm 12.5^{\mathrm{a}-\mathrm{d}}$ & 36. & $977.4 \pm 27.1 \mathrm{a}^{\mathrm{a}-\mathrm{d}}$ & 56. & $1067.3 \pm 25.2 \mathrm{ab}$ & 76. & $638.4 \pm 23.8^{f}$ & 93. & $977.4 \pm 43.5^{\mathrm{a}}$ & & \\
\hline 16. & $898.5 \pm 3.7$ a-f & 37. & $1091.7 \pm 7.5^{\mathrm{a}}$ & 57. & $745.0 \pm 88.4 \mathrm{e}$ & 77. & $1034.9 \pm 16.3 \mathrm{a}$ & & & & \\
\hline 17. & $825.4 \pm 5.9 \mathrm{c}-\mathrm{f}$ & 38. & $970.8 \pm 29.9$ a-d & 58. & $906.1 \pm 16.9$ a-e & 78. & $897.3 \pm 16.1 \mathrm{a}^{\mathrm{a}-\mathrm{d}}$ & & & & \\
\hline 18. & $832.7 \pm 5.0 \mathrm{c}-\mathrm{f}$ & 39. & $961.2 \pm 28.6$ a-e & 59. & $1029.7 \pm 23.3^{\mathrm{a}-\mathrm{c}}$ & & & & & & \\
\hline 19. & $891.5 \pm 5.7 \mathrm{a}-\mathrm{f}$ & 40. & $1092.8 \pm 30.6^{\text {a }}$ & 60. & $1085.8 \pm 32.3^{\mathrm{a}}$ & & & & & & \\
\hline 20. & $1093.0 \pm 10.2$ a & 41. & $904.4 \pm 38.5^{\mathrm{a}-\mathrm{f}}$ & 61. & $905.6 \pm 38.0$ a-e & & & & & & \\
\hline 21. & $1044.8 \pm 17.6 \mathrm{a}^{\mathrm{a}-\mathrm{d}}$ & & & & & & & & & & \\
\hline \multicolumn{4}{|c|}{$\% \mathrm{CV}=7.6 \mathrm{Fcal}=5.3^{* *}$} & & $=7.2 \mathrm{Fcal}=7.0^{* *}$ & $\%($ & $=5.6 \mathrm{~F}_{\mathrm{cal}}=16.4^{* *}$ & $\%$ & $\mathrm{~V}=8.5 \mathrm{~F}_{\mathrm{cal}}=3.1^{* *}$ & $\% \mathrm{C}$ & $=4.7 \mathrm{~F}_{\mathrm{cal}}=5.6^{* *}$ \\
\hline
\end{tabular}

$* *$ Level of significance: Means with the same letter are not statistically significant $(\mathrm{P}<0.01)$. CV: Coefficient of Variation. $\mathrm{F}_{\text {cal }}$ : Calculated $\mathrm{F}$ Value.

Sx: Standard Error 
Table 3. Total phenolic content (TPC) ( $\left.m g G A E g^{-1} d W\right)$ in genotypes belonging to different locations $(L)$

Cizelge 3. Farkl lokasyonlara (L) ait genotiplerin toplam fenolik içeriği (TPC) (mg GAE g $\left.{ }^{-1} \mathrm{dw}\right)$

\begin{tabular}{|c|c|c|c|c|c|c|c|c|c|c|c|}
\hline \multicolumn{4}{|c|}{ L1 } & \multicolumn{2}{|r|}{ L2 } & \multicolumn{2}{|r|}{ L3 } & \multicolumn{2}{|r|}{$\mathrm{L} 4$} & \multicolumn{2}{|r|}{ L5 } \\
\hline No & TPC $\quad S x$ & No & TPC $\quad$ Sx & No & TPC $\quad$ Sx & No & TPC $\quad$ Sx & No & TPC $\quad \mathrm{Sx}$ & No & TPC $\quad$ Sx \\
\hline 1. & $292.2 \pm 3.5^{\text {i-p }}$ & 22. & $371.9 \pm 4.8 c^{c^{-e}}$ & 42 & $295.5 \pm 8.6{ }^{a-c}$ & 62. & $253.8 \pm 11.3$ e & 79 . & $306.9 \pm 2 . .^{1 \mathrm{ab}}$ & 94. & $257.5 \pm 6.1 \mathrm{de}$ \\
\hline 2. & $290.6 \pm 11.3$ j-p & 23. & $312.2 \pm 8.0^{f-n}$ & 43 & $288.7 \pm 8.4$ b-d & 63. & $284.2 \pm 2.4$ b-e & 80. & $274.5 \pm 4.8^{\mathrm{c}-\mathrm{f}}$ & 95. & $286.0 \pm 4.3 \mathrm{~cd}$ \\
\hline 3. & $270.7 \pm 2.7^{\mathrm{l}-\mathrm{p}}$ & 24. & $343.6 \pm 5.3^{c-i}$ & 44 & $276.1 \pm 4.8 \mathrm{~cd}$ & 64. & 286.611 .0 b-e & 81. & $303.1 \pm 9.7 \mathrm{a}^{-\mathrm{c}}$ & 96. & $307.7 \pm 2.9 \mathrm{bc}$ \\
\hline 4. & $259.6 \pm 8.0$ o-p & 25. & $298.6 \pm 2.9$ h-p & 45 & $310.6 \pm 2.3 \mathrm{ab}$ & 65. & $292.6 \pm 5.9$ b-e & 82. & $255.7 \pm 9.9 \mathrm{f}$ & 97. & $280.2 \pm 6.2$ c-e \\
\hline 5. & $391.7 \pm 8.4$ bc & 26. & $274.9 \pm 9.1^{\mathrm{k}-\mathrm{p}}$ & 46 & $312.9 \pm 6.2 \mathrm{ab}$ & 66. & $314.5 \pm 6.9 \mathrm{a}^{\mathrm{a} c}$ & 83. & $292.8 \pm 6.4^{\mathrm{a}^{-\mathrm{d}}}$ & 98. & $243.5 \pm 3.4 \mathrm{e}$ \\
\hline 6. & $324.0 \pm 4.4^{\mathrm{e}-\mathrm{k}}$ & 27. & $319.5 \pm 16.5^{\mathrm{f}-\mathrm{l}}$ & 47 & $295.1 \pm 5.4^{\mathrm{a}-\mathrm{c}}$ & 67. & $301.5 \pm 3.1^{\mathrm{a}-\mathrm{d}}$ & 84. & $305.4 \pm 1.2 \mathrm{ab}$ & 99. & $272.0 \pm 9.4^{\text {c-e }}$ \\
\hline 7. & $272.0 \pm 8.0^{l-p}$ & 28. & $343.6 \pm 13.5^{\mathrm{c}-\mathrm{i}}$ & 48 & $235.9 \pm 3.4$ ef & 68. & $283.3 \pm 14.0$ b-e & 85. & $310.4 \pm 2.5^{\mathrm{ab}}$ & 100. & $260.6 \pm 6.1^{\mathrm{de}}$ \\
\hline 8. & $383.3 \pm 13.2 \mathrm{~cd}$ & 29. & $345.9 \pm 10.5^{\mathrm{c}-\mathrm{h}}$ & 49 & $289.1 \pm 4.4 \mathrm{~b}-\mathrm{d}$ & 69. & $277.8 \pm 13.7$ b-e & 86. & $317.8 \pm 5.3 \mathrm{a}$ & 101. & $337.2 \pm 5.9 \mathrm{~b}$ \\
\hline 9. & $324.4 \pm 8.8 \mathrm{e}^{\mathrm{e}-\mathrm{k}}$ & 30. & $346.1 \pm 5.1^{\mathrm{c}-\mathrm{h}}$ & 50 & $316.0 \pm 2.4 \mathrm{ab}$ & 70. & $342.0 \pm 10.6$ a & 87. & $286.8 \pm 6.1$ b-e & 102. & $396.1 \pm 10.6^{\mathrm{a}}$ \\
\hline 10. & $318.2 \pm 6.4^{\mathrm{f}-\mathrm{m}}$ & 31. & $298.2 \pm 7.7$ h-p & 51 & $302.1 \pm 3.99^{\mathrm{a}-\mathrm{c}}$ & 71. & $268.9 \pm 9.0$ de & 88. & $305.8 \pm 4.8 \mathrm{ab}$ & 103. & $306.5 \pm 14.7 \mathrm{bc}$ \\
\hline 11. & $435.1 \pm 5.8$ ab & 32. & $262.7 \pm 14.1^{\mathrm{n}-\mathrm{p}}$ & 52 & $295.3 \pm 4.0^{\mathrm{a}-\mathrm{c}}$ & 72. & $271.4 \pm 12.1^{\mathrm{c}-\mathrm{e}}$ & 89. & $272.6 \pm 3.1^{\mathrm{d}-\mathrm{f}}$ & & \\
\hline 12. & $306.0 \pm 8.0 \mathrm{~g}-\mathrm{o}$ & 33. & $288.9 \pm 11.4^{j-p}$ & 53 & $261.0 \pm 7.5 \mathrm{de}$ & 73. & $322.6 \pm 6.2 \mathrm{ab}$ & 90. & $260.0 \pm 9.5$ ef & & \\
\hline 13. & $333.5 \pm 10.5^{\mathrm{d}-j}$ & 34. & $304.01 \pm 3.9$ g-o & 54 & $279.2 \pm 5.0 \mathrm{~cd}$ & 74. & $298.8 \pm 6.2^{\mathrm{a}-\mathrm{e}}$ & 91. & $296.5 \pm 2.6 \mathrm{a}^{\mathrm{a}-\mathrm{d}}$ & & \\
\hline 14. & $248.7 \pm 1.9 \mathrm{p}$ & 35. & $295.9 \pm 4.3^{h-p}$ & 55 & $215.6 \pm 5.5^{f}$ & 75. & $319.1 \pm 3.3 \mathrm{ab}$ & 92. & $272.6 \pm 4.8 \mathrm{~d}-\mathrm{f}$ & & \\
\hline 15. & $380.6 \pm 12.5^{\mathrm{cd}}$ & 36. & $313.7 \pm 1.8^{f-n}$ & 56 & $278.8 \pm 8.4^{\mathrm{cd}}$ & 76. & $300.3 \pm 8.4^{a^{-d}}$ & 93. & $266.6 \pm 3.4 \mathrm{~d}-\mathrm{f}$ & & \\
\hline 16. & $353.5 \pm 3.7^{\mathrm{c}-\mathrm{g}}$ & 37. & $291.6 \pm 5.8^{j-p}$ & 57 & $304.4 \pm 5.0^{\mathrm{a}-\mathrm{c}}$ & 77. & $318.8 \pm 4.2 \mathrm{ab}$ & & & & \\
\hline 17. & $350.8 \pm 5.9 \mathrm{c}-\mathrm{g}$ & 38. & $271.0 \pm 5.8^{1-p}$ & 58 & $296.1 \pm 5.4^{\mathrm{a}^{-c} \mathrm{c}}$ & 78. & $311.6 \pm 4.7 \mathrm{a}^{-\mathrm{d}}$ & & & & \\
\hline 18. & $360.1 \pm 5.0 \mathrm{c}-\mathrm{f}$ & 39. & $295.9 \pm 8.4^{\text {h-p }}$ & 59 & $315.5 \pm 1.8 \mathrm{ab}$ & & & & & & \\
\hline 19. & $332.3 \pm 5.7 \mathrm{~d}-\mathrm{j}$ & 40. & $283.5 \pm 6.1^{\mathrm{j}-\mathrm{p}}$ & 60 & $323.4 \pm 8.1^{\mathrm{a}}$ & & & & & & \\
\hline 20. & $450.6 \pm 10.2 \mathrm{a}$ & 41. & $267.9 \pm 14.4 \mathrm{~m}-\mathrm{p}$ & 61 & $210.9 \pm 6.8^{f}$ & & & & & & \\
\hline 21. & $363.4 \pm 17.6 \mathrm{c}-\mathrm{f}$ & & & & & & & & & & \\
\hline & $\% \mathrm{CV}=4.9$ & $\mathrm{c}_{\mathrm{cal}}=$ & $3 * *$ & & $\mathrm{~V}=3.5 \mathrm{~F}_{\mathrm{cal}}=30.8^{* *}$ & & $=5.0 \mathrm{~F}_{\mathrm{cal}}=7.0^{* *}$ & & $\mathrm{~V}=3.5 \mathrm{~F}_{\mathrm{cal}}=12.1^{* *}$ & $\% \mathrm{C}$ & $=4.6 \mathrm{~F}_{\mathrm{cal}}=33.8^{* *}$ \\
\hline
\end{tabular}

$* *$ Level of significance: Means with the same letter are not statistically significant $(\mathrm{P}<0.01)$. CV: Coefficient of Variation. $\mathrm{F}_{\text {cal }}$ : Calculated $\mathrm{F}$ Value.

Sx: Standard Error 


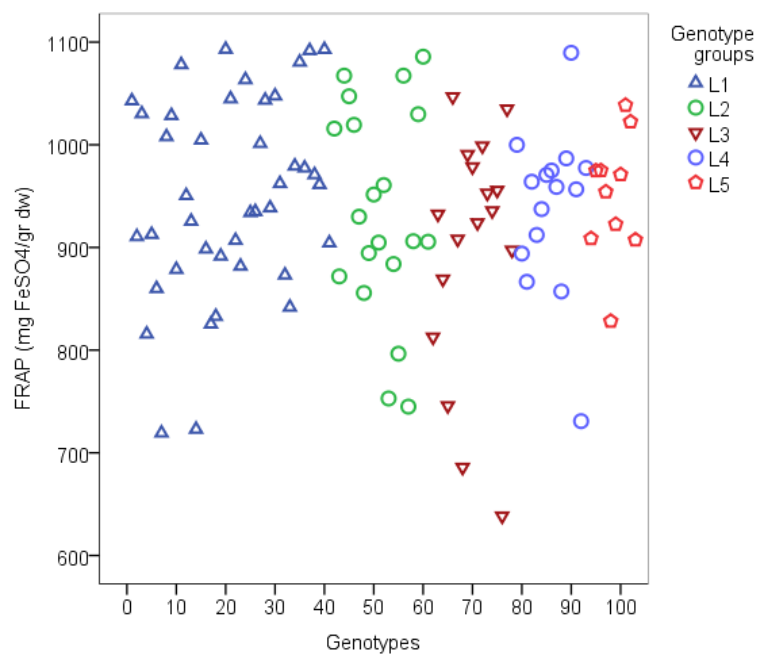

Figure 2. FRAP values of genotypes Şekil 2. Genotiplere ait FRAP değerleri

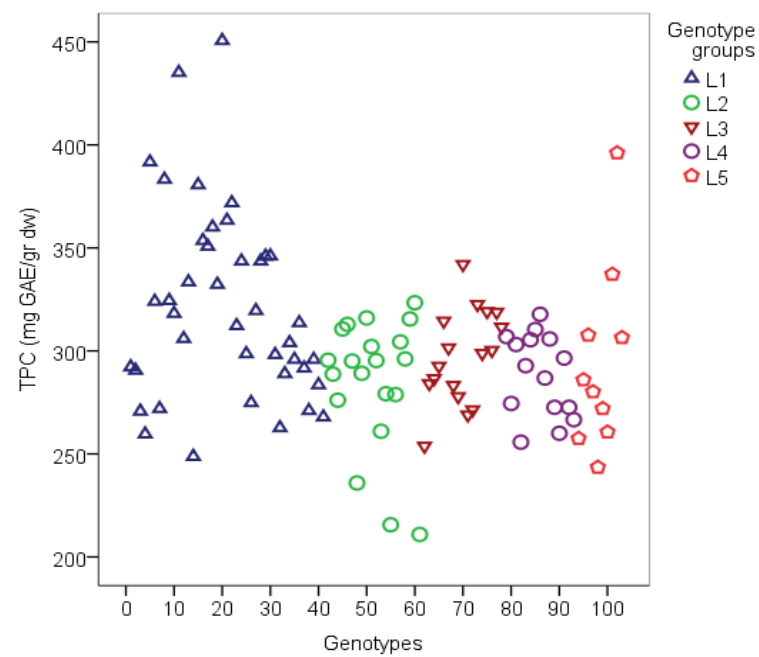

Figure 3. TPC values of genotypes Şekil 3. Genotiplere ait TPC değerleri

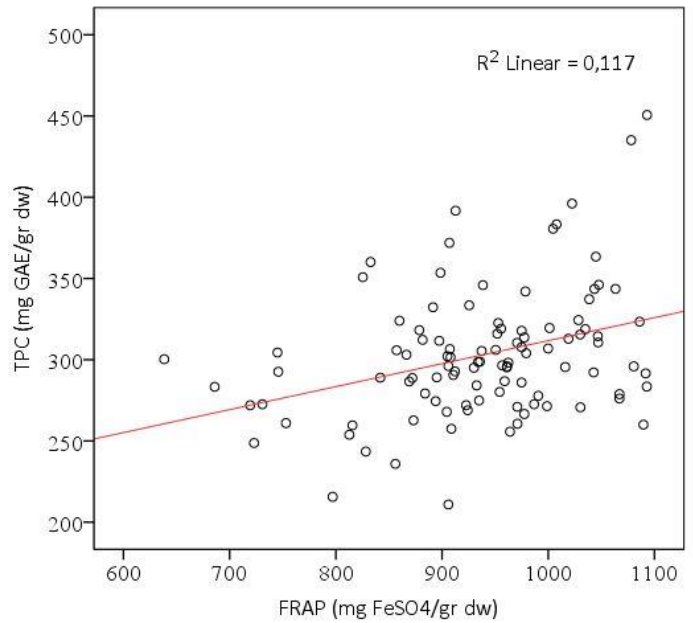

Figure 5. Relationship between FRAP and TPC Şekil 5. FRAP and TPC arasındaki ilişki

Şekil 4. Genotiplere ait FRAP ve TPC değerleri

Considering the importance of consumption of tea rich in antioxidant on human health. It could be appropriate for breeders to focus on improving genotypes showing higher antioxidant activity than approximate value of $1000 \mathrm{mg} \mathrm{FeSO}_{4} \mathrm{~g}^{-1} \mathrm{dw}$.

\section{Contribution of Authors}

The authors declare that they have contributed equally to the article.

\section{Conflict of Interest}

Article authors declare that there are no conflicts of interest among them.

\section{ACKNOWLEDGEMENT}

A part of this study is based on the data of the research supported under the TUBITAK-2209/A Project (2016/2). We thank TUBITAK for their support.

\section{REFERENCES}

Anesini C, Ferraro GE, Filip R 2008. Total Polyphenol Content and Antioxidant Capacity of Commercially Available Tea (Camellia sinensis) in Argentina. Journal of Agricultural and food Chemistry. 56: 9225-9229.

Apostolides Z, Nyirenda HE, Mphangwe NIK 2006. Review of Tea (Camellia sinensis) Breeding and Selection in Southern Africa. Chapter 2. Plant Breeding and Selection in Southern Africa. 5(1): 13-19.

Benzie IFF, Strain JJ 1996. The Ferric Reducing Ability of Plasma (FRAP) as a Measure of "Antioxidant" Power: The FRAP Assay. Analytical Biochemistry. (239): 70-76.

Benzie IFF, Szeto YT 1999. Total Antioxidant Capacity of Teas by The Ferric Reducing/Antioxidant Power Assay. Journal of Agricultural and food Chemistry. 47: 633-636. 
Cantin CM, Moreno MA, Gogorcena Y 2009. Evaluation of the Antioxidant Capacity. Phenolic Compounds. and Vitamin C Content of Different Peach and Nectarine [Prunus persica (L.) Batsch] Breeding Progenies. Journal of Agricultural and Food Chemistry. 57(11): 4586-4592.

Capocasa F, Diamanti J, Tulipani S, Battino M, Mezzetti B 2008. Breeding Strawberry (Fragaria $x$ Ananassa Duch) to Increase Fruit Nutritional Quality. BioFactors. 34: 67-72.

Carloni P, Tiano L, Padella L, Bacchetti T, Customu C, Kay A, Damiani E 2013. Antioxidant Activity of White. Green and Black Tea Obtained from The Same Tea Cultivar. Food Research International. 53: 900-908.

Ercisli S, Orhan E, Ozdemir O, Sengul M, Gungor N 2008. Seasonal Variation of Total Phenolic. Antioxidant Activity. Plant Nutritional Elements. and Fatty Acids in Tea Leaves (Camellia sinensis var. sinensis clone Derepazari 7) Grown in Turkey. Pharmaceutical Biology. 46(10-11): 683-687.

Erturk Y, Ercisli S, Sengul M, Eser Z, Haznedar A, Turan M 2010. Seasonal Variation of Total Phenolic. Antioxidant Activity and Minerals in Fresh Tea Shoots (Camellia sinensis var. sinensis). Pakistan Journal of Pharmaceutical Sciences. 23(1): 69-74.

Gonbad RA, Afzan A, Karimi E, Sinniah UR, Swamy MK 2015. Phytoconstituents and Antioxidant Properties among Commercial Tea (Camellia sinensis L.) Clones of Iran. Electronic Journal of Biotechnology. 18: 433-438.

Graham HN 1992. Green Tea Composition. Consumption and Polyphenol Chemistry. Preventive Medicine. 21(3): 334-350.

Hajiboland R, Bastani S, Rad SB 2011. Effect of Light Intensity on Photosynthesis and Antioxidant Defense in Boron Deficient Tea Plants. Acta Biologica Szegediensis. 55: 265-272.

Hajimahmoodi M, Hanifeh M, Oveisi MR, Sadeghi N, Jannat B 2008. Determination of Total Antioxidant Capacity of Green Teas by The Ferric Reducing/Antioxidant Power Assay. Iranian Journal of Environmental Health Science \& Engineering. 5(3): 167-172.

Hayakawa S, Saito K, Miyoshi N, Ohishi T, Oishi Y, Miyoshi M, Nakamura Y 2016. Anti-Cancer Effects of Green Tea by Either Anti- or Pro -Oxidative Mechanisms. Asian Pacific Journal of Cancer Prevention. 17(4): 1649-54.

Jayasekera S, Molan AL, Garg M, Moughan PJ 2011. Variation in Antioxidant Potential and Total Polyphenol Content of Fresh and Fully-Fermented Sri Lankan Tea. Food Chemistry. 125: 536-541.

Jeganathan B, Punyasiri PAN, Kottawa-Arachchi JD, Ranatunga MAB, Abeysinghe ISB, Gunasekare MTK, Bandara BMR 2016. Genetic Variation of Flavonols Quercetin. Myricetin and Kaempferol in the Sri Lankan Tea (Camellia sinensis L.) and Their Health-Promoting Aspects. Hindawi Publishing Corporation International Journal of Food Science. 9 p.

Jiang S, Li H, Ma L, Liao H, Wang Z, Fu X, Wang C 2011. Antioxidant Activities of Selected Chinese Medicinal and Edible Plants. International Journal of Food Sciences and Nutrition. 62(5): 441444.

Karori SM, Wachira FN, Wanyoko JK, Ngure RM 2007. Antioxidant Capacity of Different Types of Tea Products. African Journal of Biotechnology. 6(19): 2287-2296.

Kaur L, Jayasekera S, Moughan PJ 2014. Antioxidant Quality of Tea (Camellia sinensis) as Affected by Environmental Factors. (Chapter 13. Processing and Impact on Antioxidants in Beverages. Elsevier. Ed. Victor Preedy) 121-129.

Liu H, Qiu N, Ding H, Yao R 2008. Polyphenols Contents and Antioxidant Capacity of 68 Chinese Herbals Suitable for Medical or Food Uses. Food Research International. 41: 363-370.

Mir BA, Rasool S, Rehman MU, Amin I, Ali R 2019. Anticancer Mechanistic Insights of Epigallocatechin-3-Gallate. An Active Ingredient of Green Tea (Camellia sinensis). (Plant and Human Health. Ed. Ozturk M and Hakeem K. Springer. Cham) 2: 139-157.

Nibir YM, Sumit AF, Akhand AA, Ahsan N, Hossain MS 2017. Comparative Assessment of Total Polyphenols. Antioxidant and Antimicrobial Activity of Different Tea Varieties of Bangladesh. Asian Pacific Journal of Tropical Biomedicine. 7(4): 352-357.

Nor Qhairul Izzreen MN, Mohd Fadzelly AB 2013. Phytochemicals and Antioxidant Properties of Different Parts of Camellia sinensis leaves from Sabah Tea Plantation in Sabah. Malaysia. International Food Research Journal. 20(1): 307312.

Oh J, Jo H, Cho AR, Kim S, Han J 2013. Antioxidant and Antimicrobial Activities of Various Leafy Herbal Teas. Food Control. 31: 403-409.

Ogut S 2014. Importance of Natural Antioxidants. Journal of Adnan Menderes University Agricultural Faculty. 11(1): 25-30.

Rusak G, Komes D, Likic S, Horzic D, Kovac M 2008. Phenolic Content and Antioxidative Capacity of Green and White Tea Extracts Depending on Extraction Conditions and The Solvent Used. Food Chemistry. 110: 852-858.

Savsatli Y, Ozcan A, Catal MI, Yurteri E, Seyis F 2018. The Effect of Pruning Age and Diurnal Variability on The Antioxidant Activity of Tea (Camellia sinensis (L.) O. Kuntz) Leaves in Organic Tea Farming. Turkish Journal of Agriculture-Food Science and Technology. 6(2): 163-168. 
Scalzo J, Battino M, Costantini E, Mezzetti B 2005. Breeding and Biotechnology for Improving Berry Nutritional Quality. BioFactors. 23: 213-220.

Shannon E, Jaiswal AK, Abu-Ghannam N 2018. Polyphenolic Content and Antioxidant Capacity of White, Green, Black, and Herbal Teas: A Kinetic Study. Food Research. 2(1): 1-11.

Sirisa-Ard P, Peerakam N, Sutheeponhwiroj S, Shimamura T, Kiatkarun S 2017. Biological Evaluation and Application of Fermented Miang (Camellia sinensis var. assamica (J.W. Mast.) Kitam.) for Tea Production. Journal of Food and Nutrition Research. 5(1): 48-53.

Stushnoff C, Holm D, Thompson MD, Jiang W, Thompson HJ, Joyce NI, Wilson P 2008. Antioxidant Properties of Cultivars and Selections from the Colorado Potato Breeding Program. American Journal of Potato Research. 85:267-276.

Tariq AL, Reyaz AL 2013. Antioxidant Activity of Camellia sinensis Leaves. International Journal of Current Microbiology and Applied Sciences. 2(5): 40-46.

Taylor S 2003. Tea Types. Production, and Trade. $\left(2^{\text {nd }}\right.$ ed. Encyclopedia of Food Sciences and Nutrition. Ed. Caballero B et al. Elsevier) 5737-5743.

Tounekti T, Joubert E, Hernández I, Munné-Bosch S 2013. Improving The Polyphenol Content of Tea. Critical Reviews in Plant Sciences. 32: 192-215.

Van Hethof KH, Deboer HS, Wiseman SA, Lien N, Westrate JA, Tijburg LB 1997. Consumption of
Green or Black Tea does not Increase Resistance of Low-Density Lipoprotein to Oxidation in Humans. The American Journal of Clinical Nutrition. 66(5): 1125-1132.

Vishnoi H, Bodla RB, Kant R 2018. Green Tea (Camellia sinensis) and Its Antioxidant Property: A Review. International Journal of Pharmaceutical Sciences and Research. 9(5): 172336.

Waheed A, Hamid FS, Ahmad N 2001. Criteria Used in Selection of Locally Best Tea Bushes. Journal of Biological Sciences. 1(1): 21-23.

Wang YC, Bachrach U 2002. The Specific Anti-Cancer Activity of Green Tea (-)-Epigallocatechin-3Gallate (EGCG). Amino Acids. 22: 131-143.

Waterhouse AL 2002. Determination of Total Phenolics. (Current Protocols in Food Analytical Chemistry. Ed. Wrolstad RE et al. John Wiley and Sons) 11.11-11-18.

Weisburger JH 1997. Tea and Health: A Historical Perspective. American Health Foundation. 114(12): 315-317.

Yagi C, Ikeda N, Sato D 2010. Characteristics of Eight Japanese Tea Cultivars. College of Tropical Agriculture and Human Resources. Fruits and Nuts-15: 1-6.

Yazici K, Goksu B 2017. Effects of Kaolin (M-99-099) Application on Antioxidant and Phenolic Compounds in Tea Leaves (Camellia sinensis L.O. Kuntze). Biochemical Genetics. 55: 367-377 